\title{
The Portrayal of Women in Milton's Works: Milton's Misogyny
}

\author{
Berna Köseoğlu \\ University of Kocaeli \\ koseoglu berna@hotmail.com \\ https://dx.doi.org/10.12795/futhark.2011.06.05
}

\begin{abstract}
Analyzing John Milton's works, one can observe the influence of his personal life, his biography upon his poetry and prose. Milton, in his works, not only demonstrates the social and political issues of his own society, but he also deals with the gender issue by creating female characters who have some weaknesses or faults, which cause destruction and disaster. Therefore, his own experiences not only related to social issues but also about women and marriage play a considerable role in his depiction of the relationship between female and male. In this article, the general condition of women in the $17^{\text {th }}$ century English society and Milton's portrayal of women will be analyzed by highlighting the influence of Milton's own experiences upon his representation of gender roles.
\end{abstract}

Keywords: Milton, $17^{\text {th }}$ century English literature, gender roles, misogyny, depiction of women in Milton's works

Considering the general condition of women in the seventeenth century, there appears a close similarity between the position of women in English society and the females in Milton's works. In that period, women neither had civil, ecclesiastical rights nor proved themselves in the working arena. Due to the repression they were faced with, they had no voice or freedom in society or at home (McColley, 149). The same representation of women and the powerlessness of females can also be seen in Milton's works, and this proves the connection between the personal life and the literary life of Milton. Analyzing his works, his writings about marriage and divorce draw attention. As Fallon argues,

[w]riting about marriage and divorce, Milton relies upon union and separation. Milton the 'marrier' unites body and spirit into one substance, and treats doctrinal and moral offense as aspects of a 
single error. Milton the 'divorcer,' like the God of Paradise Lost and the Doctrine and Discipline, creates order by separation. (69-70)

Milton believes that marriage should be based on the harmony between the mind and the body of the partners, and the married couples should not be involved in immorality or unfaithfulness. Moreover, he claims that the partners should divorce if there is disorder, unhappiness or disharmony in marriage; so divorce is regarded, by Milton, as a necessity for order unless there is harmony. In The Doctrine and Discipline of Divorce (1643), Milton expresses his opinions about marriage and divorce in this manner:

That indisposition, unfitness, or contrariety of mind, arising from a cause in nature unchangeable, hindring and ever likely to hinder the main benefits of conjugall society, which are solace and peace, is a greater reason of divorce than naturall frigidity, especially if there be no children, and that there be mutuall consent. (DDD 4)

It is seen that, according to Milton, if «indisposition, unfitness, or contrariety of mind» (242) come into view in marriage institution, as it will threaten "solace and peace," divorce should take place if there is no child and if there is "mutual consent" between the female and the male. Thus, his own failures in marital life and his miseries after his marriages made him pay attention to the conflicts between partners in marriage, so he asserts, «[t]his is certain that the preservation of life is more worth than the compulsory keeping of marriage; and it is no less then cruelty to force a man to remain in that state as the solace of his life, which he and his friends know will be either the undoing or the disheartening of his life» $(D D D, 20)$. It reveals that Milton suggests divorce for men if they lead an unhappy, distressed and unbearable life with their wives. In Milton's words, unless they end their marriage, it will result in metaphorical death or «disheartening of life» (274), therefore Milton's sufferings as a consequence of his marriages and the impact of his first wife's escape can clearly be recognized in his works (McColley, 153). In this sense, paying attention to the view of the English church in Milton's time, what draws attention is that $«<\ldots>$ heresy $<\ldots>$ was the only grounds for divorce; adultery was grounds only for separation» (Henry, 24), which means that one could not divorce easily even if $s /$ he was Futhark 6 (2011) Köseoğlu, The Portrayal of Women, 93-112

ISSN 1886-9300 
dissatisfied in marital life. That is why Milton's The Doctrine and Discipline of Divorce is of great importance in terms of his emphasis on the necessity of divorce, despite the conventions of his own time. Thus, he does not have a positive attitude towards women, in this manner, he regards females just as vehicles to comfort males and eliminate the loneliness in their lives as he himself says: "God in the first ordaining of marriage, taught us to what end he did it, in words expressly implying the apt and cheerfull conversation of man with woman, to comfort and refresh him against the evil of solitary life <...>» $(D D D, 1)$. It is obvious that women, according to him, are objects for ending the distress and discomfort of loneliness in men's lives, and this shows the secondary position of women in the male-dominated society.

Not only in The Doctrine and Discipline of Divorce, but also in his Second Defence (1654), Milton focuses on marriage and the conflicts within marital life, and highlights the wide gap between wife and husband in unhappy relationships as observed: «[...] I set forth my views of marriage, not only its proper contraction, but also, if need be, its dissolution $<\ldots . .>$. Concerning this matter then I published several books, at the very time when man and wife were often bitter foes [...]” (624-26). Rather than portraying happy partners and peaceful conjugal lives, Milton prefers to dwell on the problematical marriages in which husband and wife are leading their lives as if they are enemies, accordingly in his many works he creates female characters who cause trouble and disorder, as a result of which the male finds himself in problems and chaos as well.

Analyzing his Paradise Lost (1667), what draws attention is that he depicts Eve as inferior to Adam, so there appears a female character who is described as a weak human being not only leading Adam to destruction but also causing the fall of man from paradise. In this sense, Milton's relationship with women and his marriages have an undeniable influence upon his representing women as wicked and vulnerable. Especially Milton's first wife, a seventeen-year old woman, Mary Powell played a considerable role upon his misogyny, since she left Milton a month later after their marriage, and she neither returned nor answered the letters of Milton (McColley, 153), so he attributes negative qualities to 
his female characters as it can be seen within the portrayal of Eve in Paradise Lost.

$$
\begin{aligned}
& \text { Whence true authority in men; } \\
& \text { though both Not equal, as their sex not equal seemed; } \\
& \text { For contemplation he and valour formed, } \\
& \text { For softness she and sweet attractive grace; He for God } \\
& \text { only,she for God in him. His fair large Front and Eye sublime } \\
& \text { declared Absolute rule; }<\ldots \text {... (IV 295-301) }
\end{aligned}
$$

It is obvious that inequality between Eve and Adam dominates the lines, as a consequence of which Milton's misogyny comes to fore. While authority, intelligence, and absolute rule belong to Adam; softness and attractiveness define Eve, in other words not mental but physical qualities of Eve are emphasized. In this manner, by means of Eve, Milton portrays women as acquiring just physical beauty and men as possessing mental superiority, so men and women are not demonstrated as equal. As Wittreich states, "Adam's representation of Eve as a submissive, subordinate figure [...]" (92-93) shows Milton's misogyny. It can easily be seen through his depictions related to the inequality between Adam and Eve. Adam directly appeals to God whereas Eve is subjected to Adam, therefore Adam is depicted as more heroic, intellectual and superior. In this perspective, together with Milton's negative portrayal of women in his works, the condition of women and their sufferings in marital life, in general, in the seventeenth century England, were also similar to Milton's depiction. As Weston underlines, «[the] tension between equality and submission reflects real conflicts within the experience of marriage that are specific to the seventeenth century» (69). Hence, it is impossible not to recognize the vulnerability of women both in Milton's society and in his works, therefore the physical description of Eve also strengthens women's depiction as fragile, yielding, and passive beings who have merely physical beauty, rather than mental power:

She, as a veil down to the slender $\begin{array}{r}\text { waste, } \\ \text { tresses }\end{array}$
Her unadorned
Dishevelled, but in wanton $\begin{aligned} & \text { ringlets } \\ & \text { waved }\end{aligned}$
As the vine curls her tendrils, which


Subjection, but required with gentle sway, And by her yielded, by him best received,

Yielded with coy submission < ...>. (IV 306-10)

These lines can be associated with eroticism, desire of love and Eve's inevitable subjection to Adam. Having golden tresses and wanton ringlets, she is described as a physically attractive female who can also be regarded as a temptress. As Guillory highlights, «<...> femininity is marked as the perpetual desire of the female to return to the body image» (207), as a consequence sexuality and femininity of women, instead of their intelligence, can be observed in Paradise Lost. Despite her active role in terms of attracting the attention of males, she is, at the same time, defined as a subservient, submissive woman subjected to male authority. As Jarvis states, "Eve is constituted, paradoxically, as an unequal half $\langle\ldots\rangle$. Masculine love is thus primary, superior and literal; feminine love is secondary, submissive and figurative" (147), consequently Adam's love towards Eve is more superior and dominant than Eve's love, so while she represents femininity and sexuality, Adam symbolizes power, passion of love, and masculine authority. Moreover, Eve herself also accepts Adam's superiority, leadership, and his mental power, as a result of which she can not find the right way, the light without Adam as seen along these lines:

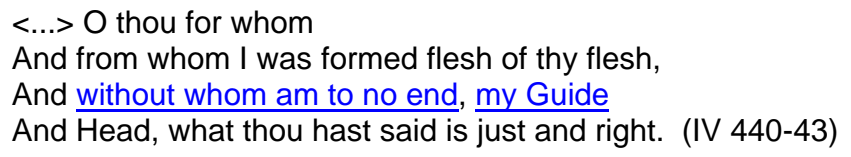

It is clear that Eve does not hesitate to stress that she is bound to Adam since she comes from his flesh, so without him, she is not strong enough to survive, which shows that Adam, in other words, the male, is the one who controls, guides and dominates the female; therefore "God making Eve from Adam's rib, suggests a sex that is subordinate perhaps created only secondarily in God's image and so spiritually inferior» (McColley, 150), consequently Adam is depicted as the Guide and the Head, which means that he is the one who has the mental power and who has the capacity to show the right and the wrong, 
in a sense, as Bush underlines, "he [Milton] assumed the superior status of men in the chain of being" (86), so Milton implicitly indicates that women can not stand on their own feet unless they are protected and ruled by men, and they need the guidance, advice and intelligence of males. This situation comes from his unfortunate experiences with women, since «he was responsive to female beauty and had a lofty view of marriage as a rare companionship of mind as well as body, but he had little direct experience of women» (Lewalski, 156), so his biography had an undeniable impact upon his portrayal of women.

Milton, drawing such a weak portrait of a female, like Eve. in Paradise Lost, also highlights that women can easily be manipulated due to their weaknesses, therefore, Eve is easily deceived by Satan, who tries to urge her to pay attention to the pleasures of the outside world as it is observed:

O Sole in whom my thoughts find all repose,

My glory, my perfection, glad I see

Thy face, and Morn returned, for I this Night,

Such night till this I never passed, have dreamed,

If dreamed, not as I oft am wont, of thee, <...>. (V 28-32)

Close at mine ear one called me forth to walk

With gentle voice, I thought it thine; it said,

Why sleep'st thou Eve? now is the pleasant time,

The cool, the silent, save where silence yields

To the night-warbling Bird, that now awake

Tunes sweetest his love-laboured song; now reigns

Full-orbed the Moon, and with more pleasing light. (V 36-42)

It is seen that Satan, taking Eve under his own control, tries to subvert her so as to cause the fall of man from heaven, so the voice she hears in her dream, Satan's voice, draws her attention to the birds singing love songs, the perfection and pleasures of environment. She is depicted by Milton as such a weak female that she believes that the voice belongs to Adam, who is her "glory" and "perfection." Thus, as Steadman indicates, " $<\ldots>$ frailty and credulity underlay woman's vulnerability to the delusions of [...] Eve's vulnerability to Satan's temptation» (161), so Eve's powerlessness in front of Satan is related to 
Milton's misogyny. While Adam symbolizes all the positive qualities that make an individual superior, Eve represents all the negative characteristics which make her portrayal more and more vulnerable, therefore they are «in a hierarchical relationship of greater and lesser, superior and inferior» (Green, 301). Manipulated by the rhetorical words of Satan, she unconsciously finds herself under the invisible command of Satan:

$<\ldots>$ Natures desire,

In whose sight all things joy, with ravishment

Attracted by thy beauty still to gaze. (V 45-47)

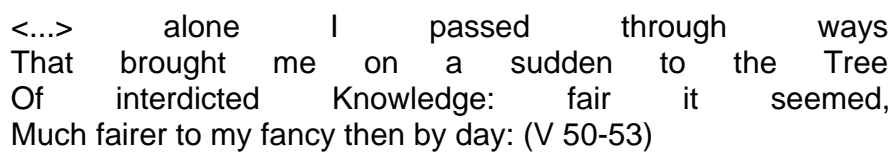

Praising her beauty and provoking her to realize the magnificence of the tree of Knowledge in paradise, Satan comes into view as the tempter of Eve, who can not use her intelligence to make her decisions, in this outlook, it is doubtless that «Milton accepts the concept <...> that man is superior and woman inferior in terms of reason, which is superior to emotion" (Shawcross, 208). Hence, Eve is depicted as being defeated because of her emotions and due to her inferiority in terms of her reason, so she is influenced by Satan's celebrating her beauty and his portrayal of the Garden of Eden and the Tree of Knowledge, as a consequence she provokes Adam to work separately so as not to be so close to one another, which may prevent them from focusing on their work:

Adam, well may we labour still to dress This Garden, still to tend Plant, Herb and Flour,

Our pleasant task enjoined, but till more hands

Aid us, the work under our labour grows. (IX 205-08)

Let us divide our labours, thou where choice Leads thee, or where most needs, whether to wind. (IX 214-15) 


For while so near each other thus all day
Our task we choose, what wonder if so near
Looks intervene and smiles, or object new
Casual discourse draw on, which intermits
Our day's work brought to little. (IX 220-24)

In order to persuade Adam to divide their labour and to work alone, Eve indicates that if they work together, they can not produce more and their concentration will be interrupted due to their love towards one another. In this respect, Milton dwells on women's capacity to use their femininity to lead men to destruction, so Eve, for the sake of enjoying the beauties of the outside world, tries to make Adam believe the necessity not to work together. Although Adam is depicted more intelligent than Eve, he is persuaded by her because of his intense love towards her. Though he says, «<...> we need/Refreshment, whether food, or talk between,/Food of the mind, or this sweet intercourse/Of looks and smiles, for smiles from Reason flow,/To brute denied, and are of Love the food, /Love not the lowest end of human life» (IX 236-41), he will be persuaded by Eve. In this manner, Adam praises love by stressing that smiles, looks and the speeches between the lovers are the symbols of their love, therefore there is no need to fear love. Here, Milton's interest in love and the relationships between the lovers comes to fore, since he himself appreciated love and married three times though he failed in his marriages. Furthermore, Adam is described not only as taking pleasure of love but also as a sensible male who can use his intelligence and who can recognize what is good and bad, because he feels the danger they will be faced with, in other words Satan's intention to cause their fall, and suggests Eve not to separate: «Envying our happiness, and of his own/Despairing, seeks to work us woe and shame» (IX 254-55). Milton's misogyny once more appears within his portrayal of Adam, who has enough mental power to predict the events and threats they will encounter, and who has «intellectual superiority» (Gross, 99), whereas Eve represents the women who are less intelligent and rational than men, because it is Eve who will change Adam's decision and cause him to disobey the rules of God. 
Milton also idealizes the portrayal of women by attributing them merely the domestic issues and by stressing that they should deal with the household and obey their husbands, in a word, the females exist for satisfying the males, hence "[Eve's] creation for him [Adam], as a remedy of his loneliness" (Nyquist, 178) also justifies the secondary position of women in front of men ; as a result the male-domination, the superiority of patriarch dominate Milton's work as recognized in Adam's words:

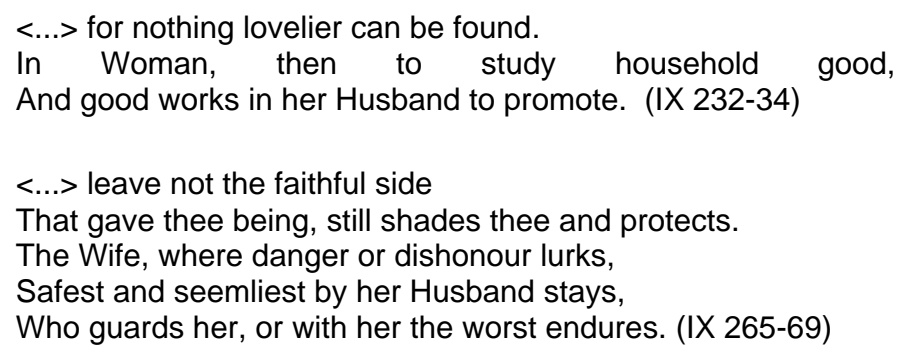

It would not be wrong to assert that women, in general, are depicted by Milton, as powerless, helpless beings who must satisfy and be loyal to their husbands by submitting to their commands and accepting to be under the hegemony of them. As Shawcross claims, «Milton [is] placing man in a superior position to woman, as the 'head', as the dominant in the relationship of husband and wife» (12). Rather than taking their own decisions, determining what to do, or enjoying freedom, the females, according to Milton's depiction, must be docile under the protection and the control of the males and deal with just the issues about household. This means that Milton illustrates such a passive portrayal of women that they are not allowed to prove themselves and to express their individuality. Accordingly, as Turner argues, "[t]he general assumption [in Paradise Lost], of course, is that the wife should be subordinate». In this respect, Milton's description of Eve and her being tempted by Satan can be associated with Milton's misogyny, since she is depicted such a feeble being that she is deceived by Satan, in the form of a serpent in this manner: 


Thee all things living gaze on, all things thine
By gift, and thy celestial beauty adore
With ravishment beheld, there best beheld
Where universally admired [...]. (IX 539-42)

Who sees thee? (and what is one?) who shouldst be seen A Goddess among Gods, adored and served By Angels numberless, thy daily train? (IX 546-48)

Satan, playing on Eve's pride, tempts her by praising her beauty and imposing his destructive plan upon her, therefore he emphasizes that all the living creatures are so influenced by her "celestial beauty" (IX 540) that they admire and adore her; on the other hand as she is by herself with just Adam, it is only Adam who sees her, and appreciates her beauty, so indicating her imprisoned and restricted life, he forces her to break the rules of God and enjoy the pleasures in the Garden of Eden, consequently as Tanner states, both the «internal and external causes» will be influential in the fall of man from paradise (45), because while Eve seems to be the internal cause, Satan is the external factor, invisibly tempting Eve, and to deceive Eve, he gives information about the wonders of the Tree in the Garden of Eden:

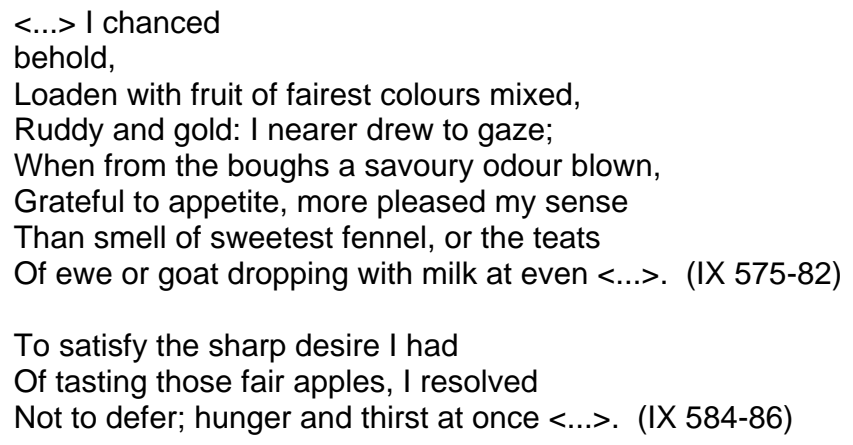


Satan, aiming at deceiving Eve, celebrates the perfection of the fruits with various colours, and of the nice smell of these fruits, which is more pleasing than the smell of the «sweetest fennel, the teats of ewe or the milk of a goat» (IX 581-82). Emphasizing the desire of tasting the forbidden apple, his hunger and thirst for this fruit, he implicitly manipulates Eve and tries to persuade her to eat that apple, which would make her attain Knowledge and discover the wonders of the universe. In this sense, Milton also highlights the curiosity in the nature of women, which causes destruction and many undesirable results, so Eve's questioning the tree by asking, «[W]here grows the tree? From hence how far?» reveals the curious side of females and also Milton's criticizing this attitude, because in his work due to Eve's weakness, the violation of God's order and the fall of man take place. In addition to her curiosity, she has also another weakness, which is her naive nature and susceptibility to the praises of Satan, who compares her beauty to all the things in Nature and on Earth:

I turned my thoughts, and with capacious mind
Considered all things visible in Heaven,
Or Earth, or Middle, all things fair and good.
But all that fair and good in thy divine
Semblance, and in thy Beauties heavenly ray,
United I beheld- no fair to thine. (IX 603-08)

Satan not only implies that he knows everything on Earth, but he also underlines that Eve is more beautiful than all of the fair and good things in Heaven, and Earth, thus as a vulnerable female, and easily deceived woman, Eve is highly influenced by the temptation of Satan. Eve thinks that if she tastes the forbidden fruit, she can also attain the knowledge, the joys and all the fair things in heaven, as a consequence of which Milton's presenting women with weaknesses, inabilities, passions again comes into view. Eve, being tempted by Satan to eat the forbidden fruit, tries to tempt Adam and to persuade him to taste it as well, in this outlook she comes into sight as a temptress, which also shows Milton's misogyny:

This tree is not, as we are told, a tree

Of danger tasted, nor to evil unknown 
Opening the way, but of divine effect

To open eyes, and make them gods who taste $<\ldots$. . (IX 86366)

Thou therefore also taste, that equal lot May join us, equal joy, as equal love; Lest thou not tasting, different degree Disjoin us <...>. (IX 881-84)

Through Milton's depiction of Eve, what should be stressed is that she does not have enough cleverness and mental capacity to realize Satan's intention to cause the fall of man from paradise and to cause chaos. Since she is deceived by Satan, who has convinced her to believe that she will gain power, intelligence and reach a higher status after tasting the fruit, she also leads Adam to destruction by indicating the necessity for him to eat the same fruit. She asserts that after tasting it, she has turned out to be a God-like figure, more superior, more knowledgeable and more powerful than Adam. In this sense, she implicitly forces Adam to violate God's rule by saying that since she is more intelligent than him due to the knowledge she has attained with the forbidden fruit, the difference in terms of their mental state may disjoin them and cause inequality. Thus, «[t]he temptation Eve designs for Adam is a love trial. He must again reckon her worth. And again, he pays the price <...>» (Kerrigan and Braden, 154). By indicating that their love should be based on equality, she obliges Adam to taste the fruit to achieve equal love. Hence, it is doubtless that Milton creates such an ambitious and cunning female character that she subverts Adam by using her femininity. In this respect, Adam's blaming Eve for her disobeying God's order, tasting the forbidden fruit, and making him taste it as well can be analyzed in terms of Milton's misogyny:

Would thou hadst hearkened to my words, and stayed
With me, as I besought thee, when that strange
Desire of wandering this unhappy morn,
I know not whence possessed thee; we had then
Remained still happy, not as now, despoiled
Of all our good, shamed, naked, miserable. (IX 1134-39)


It is obvious that Adam as a male accuses Eve of disregarding his orders and bringing about misery and disaster. In fact, not Adam, but Milton speaks, and highlights that if Eve had not been so curious about wandering in heaven and discovering the wonders of paradise by eating the forbidden fruit and by forcing Adam to taste it, they would not be shamed, naked and miserable. This reveals Milton's depicting women as problematic, destructive and feeble human beings, causing disorder and corruption, «because the fall was not necessitated by the will of God but rather resulted from an act of human violation» (Featheringill, 171), from the violation of Eve, who also forces Adam to violate the order of God.

Together with the negative portrayal of Eve in Paradise Lost, the same description of another female character, Dalila, in Milton's Samson Agonistes (1671) comes into view. Samson's suffering and fall come after his revealing his secret, the power he possesses through his hair, to his wife Dalila, and Dalila's spreading the secret to Philistines. This demonstrates the destructiveness of love and the inevitable disasters that will take place because of women's weak and unfaithful nature. As Loewenstein says, «the lonely, wretched Samson with whom Milton compares the husband who finds himself tragically entrapped in an unhappy marriage <...>» (128) should be taken into account. Since Dalila's sharing Samson's secret with the Philistines leads to Samson's hair's being cut off and his loss of power, Samson becomes miserable, powerless and left behind with his despair, as a result it is clear that Milton's own background and his own discontent because of his unhappy marriages can easily be observed, subsequently as Flesch states, «[t]he dark steps of Samson are also the dark steps of Milton <...> (140), thus Milton, portraying a negative picture of women, emphasizes that it is a female, Dalila, who brings about such a disaster, so Samson says:

Who, like a foolish pilot, have shipwrecked

My vessel trusted to me from above,

Gloriously rigged, and for a word, a tear,

Fool, have divulged the secret gift of God

To a deceitful woman? Tell me, friends,

Am I not sung and proverbed for a fool

In every street? <...>. (S A 198-204) 
It is seen that Samson blames himself for his weakness, in other words, for his sharing his secret with Dalila, therefore Milton means that women can not keep secrets and can not be faithful to their husbands due to their weaknesses and their changing, inconsistent nature, consequently Milton's misogyny once more appears. Samson realizes that he should not have revealed his secret and betrayed God, as Adam realizes that he should not have eaten the forbidden fruit and disobeyed God. Like Adam, Samson also accuses a female of her destroying harmony and order, so he says, «My wife, my traitress, let her not come near me» (725), so he regards his wife as a tyrant and a treacherous, and Dalila, as a female character, who is depicted as a wicked and unfaithful woman, tries to defend herself and to apologize to Samson by stressing that she could not foresee the terrible results of her betrayal:

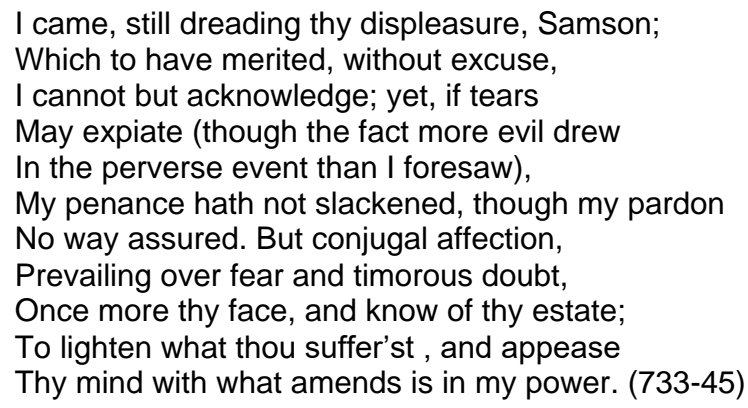

What Dalila highlights is that despite her fear, doubts, and shame, she has no hesitation to be with him so as to console him and express her anguish and disgrace. With her tears, she wants to show her affection, regret, and misery for Samson's suffering, and points out that she wants to reduce his pain and compensate for her mistake and betrayal though she is aware of the fact that it is hardly possible. It is, again, observed that Milton draws a negative portrayal of a female, who brings about nothing, but destruction and tragedy. In this respect, Samson, as the mouthpiece of Milton, states women's unreliable characteristic and their general shortcomings: 
Out, out, hyena! These are thy wonted arts, And arts of every woman false like thee-

To break all faith, all vows, deceive, betray;

Then, as repentant, to submit, beseech, <...>.

Confess, and promise wonders in her change-

Not truly penitent, but chief to try

Her husband, how far urged his patience bears, $\langle\ldots\rangle$.

(748-51, 753-55)

It is observed that Milton, through the words of Samson, expresses his misogyny by asserting that all women are the same, because all of them are false, betraying men with their arts, tricks, so they, like Dalila, have no hesitation to «break all faith, vows, deceive, betray» (750), which proves that though they seem to repent and submit to their husbands and beseech them, they, in fact, try to deceive their husbands, so this generalization about women belongs not to Samson but to Milton. Hence, this description shows the intense impact of Milton's unhappiness because of his marriages and also reflects the close relationship between his experiences with women and his portrayal of female characters in his works. This justifies that Milton was extensively influenced by his own relationships with women in his marriages. Dalila, herself, also admits that all women are weak and it is impossible for them to keep secrets:

First granting, as I do, it was a weakness

In me, but incident to all our sex,

Curiosity, inquisitive, importune

Of secrets, then with like infirmity

To publish them - both common female faults -

Was it not weakness also to make known,

For importunity, that is for naught,

Wherein consisted all thy strength and safety? <...>

$<\ldots>$ and should not

Nor should'st thou have trusted that to woman's frailty $<\ldots>$.

(774- 80, 782-83)

Through the words of Dalila, Milton makes it certain that all the females are curious, questioning and revealing secrets due to their weak nature, consequently it is not Dalila's, but Samson's fault not to keep his 
secret, because according to Dalila, though it is a well known fact that one should not share his secrets with a female, Samson, despite this reality, tells Dalila his secret and disregards «woman's frailty» (783). Hence, once more, Milton comes to the fore as a misogynist, who believes in the inequality between women and men and who indicates the fragile nature of women. On the other hand, at the same time, Milton illustrates Dalila not only as a frail woman, but also as a selfish and manipulating female as seen:

$$
\begin{aligned}
& <\ldots>\text { I saw thee mutable } \\
& \text { Of fancy; feared lest one day thou would'st leave me }<\ldots>\text {. } \\
& \text { No better way I saw than by importuning } \\
& \text { To learn thy secrets, get into my power }<\ldots>\text {. (793-94, 797-98) } \\
& \qquad<\ldots>\text { I was assured by those } \\
& \text { Who tempted me that nothing was designed } \\
& \text { Against thee but safe custody }<\ldots>\text {. (800-02) } \\
& <\ldots>\text { I knew that liberty } \\
& \text { Would draw thee forth to perilous enterprises } \\
& \text { While at home sat full of cares and fears, } \\
& \text { Wailing thy absence in my widowed bed; } \\
& \text { Here I should still enjoy thee, day and night, } \\
& \text { Mine and love's prisoner, not the Philistines. (803-08) }
\end{aligned}
$$$$
<\ldots>\text { I was assured by those }
$$

Dalila, stressing that she learnt and revealed Samson's secret in order to keep Samson under her own control, tries to underline that she feared that Samson would leave her for other women, so she defends herself by asserting that due to the intensity of her love, she could not keep the secret. Moreover, her claiming that the Philistines promised her not to give harm to Samson, can be regarded as another excuse she finds to persuade Samson to believe in her innocence. Furthermore, Milton tries to show the tricks women put into practice, by means of Dalila's stratagems. She says that she could not put up with his loss and his being captured by the Philistines and it would be unbearable for her to be a widow if they had killed him, so she says that she preferred to make him the prisoner of her love, not the captive of the Philistines. In this respect, Milton highlights that all women, like Dalila, can easily create excuses for their betrayals and faults and easily deceive the males with nice words. Besides, the following lines are of importance, in 
which she stresses that with the power of her love towards him, she challenged the pressure of the Philistines over her: «<...> What had I/To oppose against such powerful arguments?/Only my love of thee held long debate;/And combated in silence all these reasons/With hard contest» (861-65). Thus, her indicating that she resisted the pressure of the authority for some time for the sake of her love, proves the negative portrayal of females deceiving the males with their tricks. In this respect, the words Milton deliberately chose and the depth of meaning within his lines effectively shed light on his dissatisfaction and failures with women and the inevitable influence of these experiences upon his poetry, so as Bloom asserts, «Milton's wit, his control of rhetoric, [is] again the exercise of the mind <...>» (29), as a result of which the intensity of meaning and the subtlety in terms of poetic quality comes to the fore.

Finally, it is apparent that Milton, having experienced unhappy marriages and failures with his relationships with women, portrayed in his works, a negative approach towards women. Reflecting them as vulnerable, unfaithful, unreliable individuals, he underlined the superiority, power and intelligence of men, in a sense, he stressed the inequality between them. In the light of his ideas about women and his depicting them with physical beauty, without mental power, it would not be wrong to assert that his own experiences related to females had an enormous impact upon his negative portrayal of his female characters in his works as it is seen in Paradise Lost and Samson Agonistes. Moreover, his misogyny and his emphasis on the necessity of divorce for the unhappy couples can also be recognized in his The Doctrine and Discipline of Divorce and Second Defence. Thus, it is impossible not to realize the power and subtlety of his language in his poetry and his use of literature in order to express his personal opinions about women.

\section{BIBLIOGRAPHICAL REFERENCES}

BLOOM, Harold, «Milton and Transumption», in BLOOM, Harold (ed.), John Milton's Paradise

Lost, New York, Chelsea House P, 1987. 13-30. 
BUSH, Douglas, John Milton: A Sketch of his Life and Writing, New York, Macmillan, 1965.

FALLON, Stephen M, «The Metaphysics of Milton's Divorce Tracts», in LOEWENSTEIN,

David and TURNER, J. Grantham (eds.), Politics, Poetics and Hermeneutics in Milton's

Prose, Cambridge, Cambridge UP, 1990. 69-83.

FEATHERINGILL, Ron, The Tension between Divine Will and Human Free Will in Milton and

the Classical Epic Tradition, New York, Peter Lang, 1990.

FLESCH, William, «Reading, Seeing, and Acting in Samson Agonistes», Critical Essays on John

Milton, New York, G.K. Hall and Co, 1995. 131-48.

GREEN, Mandy, «The Vine and her Elm: Milton's Eve and the Transformation of an Ovidian

Motif», The Modern Language Review. 91.2 (Apr. 1996): 301-16 $<$ http:// www.jstor.org/ stable/3735013>.

GROSS, Barry Edward, "Free Love and Free will in Paradise Lost», Studies in English

Literature, $\quad$ 1500-1900. $7.1 \quad$ (Fall 1967): 95-106 $<$ http//www.jstor.org/stable/449459>.

GUILLORY, John, «Milton, Narcissism, Gender: On the Genealogy of Male Self-Esteem»,

Critical Essays on John Milton. New York, G.K. Hall and Co, 1995.194-230.

HENRY, Nathaniel H, The True Wayfaring Christian: Studies in Milton's Puritanism, New York,

Peter Lang, 1987. 
JARVIS, Robin, Wordsworth, Milton and the Theory of Poetic Relations, London, Macmillan, 1991.

KERRIGAN, William, and BRADEN, Gordon, «Milton's Coy Eve: Paradise Lost and Renaissance», in BLOOM, Harold (ed.), John Milton's Paradise Lost, New York, Chelsea House P, 1987. 133-57.

LEWALSKI, Barbara K, The Life of John Milton: A Critical Biography, Oxford, Blackwell, 2000.

LOEWENSTEIN, David, Milton and the Drama of History: Historical Vision, Iconoclasm, and the Literary Imagination, Cambridge, Cambridge UP, 1990.

MCCOLLEY, Diane K, «Milton and the Sexes», The Cambridge Companion to Milton. Ed.

Dennis Danielson. Cambridge, Cambridge UP, 1999. 147-66.

MILTON, John, «The Doctrine and Discipline of Divorce», 1643. March 2008. 5 Jan. 2009 $<\mathrm{http}: / /$ www.

Dartmouth.edu/ milton/reading_room/ddd/...1/text.shtml>. «Second Defence», 1654. The Complete Prose Works of John Milton. Ed. Don M. Wolfe. Vol. 4. New Haven, Yale UP, 1983.

«Paradise Lost», 1667. The English Poems of John Milton. London, Wordsworth, 2004. «Samson Agonistes»,1671. John Milton: The Complete English Poems. London, Everyman's Library, 1992. 
NYQUIST, Mary, «Gynesis, Genesis, Exegesis, and the Formation of Milton's Eve», in

GARBER, Marjorie, Cannibals, Witches, and Divorce, London, The Johns Hopkins UP,

1987. 147-208.

SHAWCROSS, John T, John Milton: The Self and the World, Lexington, The U P of Kentucky,1993.

STEADMAN, John M, Milton's Biblical and Classical Imagery, Pittsburgh, Duquesne UP, 1984.

TANNER, John S, «Say First What Cause: Ricoeur and the Etiology of Evil in Paradise Lost», Modern Language Association. 103.1 (Jan. 1988): 455-56 http:// www.jstor.org/ stable/ 462461>.

TURNER, James Grantham, One Flesh: Paradisal Marriage and Sexual Relations in the Age of Milton, Oxford, Clarendon, 1987.

WESTON, Peter, John Milton: Paradise Lost, London, Penguin, 1990.

WITTEREICH, Joseph, Feminist Milton, New York, Cornell UP, 1987. 